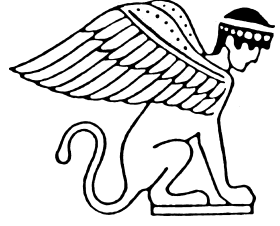

क्राтाँ

\title{
В.И.Марахонов
}

\section{ЭКОНОМИКА РАСПРЕДЕЛЕНИЯ}

Сейчас стало очень увлекательным занятием читать экономические прогнозы развития российской экономики полуторагодовой давности и сравнивать их с реалиями сегодняшнего дня. Однако, обращаясь к последним предкризисным годам, полным самого безудержного государственного оптимизма, многие вспомнят чувство смутной тревоги, охватывавшее их уже тогда. Задумчивое замечание соплеменников принца Датского, увидевших призрак на крепостной стене: «Подгнило что-то в датском государстве», - давно вызывало у наших соотечественников приступ легкой ностальгии по старым добрым временам. Почему-то становилось интуитивно ясно, что в современном российском государстве не что-то подгнило, а гниет все, что может гнить: экономика, образование, наука, здравоохранение, армия... Правда, ароматы выхлопных газов Мерседесов последних моделей, БМВ Х-5, Ягуаров, а также расплодившихся в последние годы Порше Кайенов и Хаммеров заглушали гнилостные запахи, но они все-таки пробивались и мешали наслаждаться праздником. Бодрые заявления об экономической стабильности и усиливающейся инвестиционной привлекательности России отчего-то вызывали в памяти заклинания периода застоя о незыблемости руководящей роли КПСС и т.п. Так же как и в последние годы застоя, большинство старалось не думать на эти темы и не замечать гнилостной атмосферы, пытаясь убедить себя в том, что на самом деле все прекрасно. Если зарплата или доход от бизнеса превышали средние величины, это удавалось лучше, если превышали намного - то совсем хорошо, особенно во время отдыха за рубежом. Например, кушая свежеприготовленного сибаса на террасе прибрежного ресторана где-нибудь в Барселоне. Интересно, что такой же сибас в московском или петербургском ресторане помогал гораздо хуже - то ли свежесть была не та, то ли атмосфера другая.

Убеждать себя в том, что дела идут прекрасно, становилось, однако, все труднее, и все чаще всплывали два извечных русских вопроса: «кто виноват?» и «что делать?». Писали о повальной коррупции, о разворовывании всего, что можно, о разрушении инфраструктуры, о коллапсе какой-либо политической жизни, о вымирании русского народа (и других тоже), о падении морали и о многом другом. Список каждый желающий может пополнить сам - тем предостаточно, и каждая из них такова, что ее одной хватит на объяснение всего.

В то же время автора этой статьи, по служебной необходимости имеющего дело с российским бизнесом и промышленностью, давно преследовало ощущение, что советская и унаследовавшая ей российская экономика содержат в себе некий фундаментальный системный 
порок, который не только не позволяет им нормально развиваться и душит на корню любые благие намерения, но и является первопричиной очень многих мерзостей в российской общественной жизни, казалось бы прямо с экономикой не связанных. Это ощущение особенно усилилось, когда стало ясно, что посланный Богом валютный дождь нефтяных денег совершенно бездарным образом профукивается и разворовывается и конца этому не видно. Постепенно у меня сложилось определенное ви́дение того, в чем этот порок состоит, которое я и хочу предложить на суд читателей. Наверно, многое из здесь написанного уже говорилось, многое является новым для меня, но не для специалистов в данных вопросах, тем не менее мне показалось небесполезным свести воедино свои соображения и попытаться более или менее связно их изложить.

Для начала приведу несколько простейших общетеоретических положений. Любое капиталистическое предприятие работает, чтобы получить прибыль. Кто еще застал политэкономию, помнит известный пассаж о том, что «нет такого преступления, на которое не пошел бы капитал» для получения то ли ста, то ли двухсот процентов прибыли (забыл точную цифру). Так вот, все способы получения прибыли можно разделить на четыре группы. Первые две базируются на известном законе Ломоносова-Лавуазье, гласящем, «что ежели где-либо что-либо прибудет, то беспременно где-либо что-либо соответственно убудет». Одна из них сводится к разнообразным способам отъема (путем принуждения или выманивания) денег/товаров у других физических или юридических лиц, вторая, несколько более продвинутая, - к той или иной форме эмиссии дополнительного количества денег. Поскольку, согласно монетарной теории, сумма цен товаров и услуг, обращающихся на рынке, равна количеству денег, умноженному на скорость их оборота, и чем больше денег в стране, тем выше цены, через некоторое время эта эмиссия приведет к повышению цен, и то, что прибыло у эмитентов, равномерно убудет у всех остальных держателей денег. Классическими примерами использования данного способа получения прибыли являются изготовление фальшивых дензнаков и эмиссионная деятельность государства.

Две другие группы более интересны, потому что вышеупомянутый закон Ломоносова-Лавуазье, по крайней мере в такой прямой форме, там не действует. Первая - это оказание услуг, когда за отданные деньги клиент получает, скажем, постиранную рубашку или убранный двор, то есть некий нужный ему эквивалент отданных денег. Хотя услуги, конечно, категория довольно сложная, особенно с точки зрения своей полезности, ибо если перегородить клиенту вход в его собственный дом и брать с него плату за открывание шлагбаума, то формально это тоже будет услугой, но какой-то не совсем правильной. 
Наконец, последняя, четвертая, группа, на которой, собственно, и строится экономика государства, - это получение прибыли через создание добавленной стоимости. В силу фундаментальности понятия стоимости о нем написаны горы литературы, но мне не хочется влезать в детали, анализируя разницу между прибавочной стоимостью по Марксу и предельной полезностью по Чемберлену и т.п. Достаточно констатировать, что добавленная стоимость есть то, на что увеличивается стоимость, полезность, нужность (дальше продолжите сами) продукта по сравнению со стоимостью тех компонентов, из которых он произведен. Объем добавленной стоимости зависит от того, насколько более сложным является конечный продукт по сравнению со своими исходными компонентами. По этой причине при производстве компьютера добавленной стоимости получается обычно больше, чем при производстве европоддона.

Современная промышленность высоко специализирована и предполагает широкое разделение труда. Поэтому применительно к государству нужно говорить о системе создания добавленной стоимости, состоящей из многих элементов. Прежде всего это совокупность фирм и корпораций, взаимодействующих друг с другом в производстве конечного продукта. Часть из них производит сам конечный продукт, необходимый потребителям, часть - промежуточные продукты и услуги, потребляемые другими фирмами, то, что называется В2B (business to business). Эти фирмы и корпорации укомплектованы штатом специалистов, разбирающихся в технологии производства, и штатом менеджеров, знающих, как это производство организовать оптимальным образом, чтобы фирма приносила максимальную прибыль. Существует также система подготовки подобного рода специалистов и менеджеров. Поскольку корпорация, чья продукция устарела, со временем неизбежно превратится в убыточную, происходит постоянное обновление продукции; соответственно, существует штат людей, обеспечивающих такое обновление. Существуют специалисты по маркетингу, чьей задачей является установление максимально эффективных связей с клиентами и партнерами и определение того, сколько единиц продукта надо произвести, чтобы его купили, а не оставили на полках за ненадобностью. Существует система кредитного и инвестиционного финансирования, позволяющая направлять деньги в прибыльные отрасли экономики. Наконец, существуют законы, призванные подавлять деятельность, нацеленную на получение прибыли по закону Ломоносова-Лавуазье. К простейшим из этих законов относятся те, что сведены в Уголовный Кодекс, но по мере развития государства появляются и более сложные, в основном касающиеся финансовой сферы.

В случае, когда речь идет о высокотехнологичной продукции, требуется и система высшего специального образования, а также научных, инженерных и конструкторских школ, поддерживающих уровень подготовки кадров, достаточный для того, чтобы обеспечить непрерывное движение вперед. Создавать новую высокотехнологичную продукцию - 
дело чрезвычайно сложное, но без постоянного обновления высокотехнологичная продукция быстро перестает быть таковой. Кроме того, степень специализации и разделения труда, равно как и доля В2В, в отраслях данного типа значительно выше, чем в остальных.

Именно создание добавленной стоимости является тем способом получения прибыли, который содействует развитию экономики государства - как, впрочем, и государства вообще, ибо без развитой экономики ни наука, ни искусство, ни обороноспособность развиваться не будут. Поэтому вменяемое государство должно всячески поддерживать систему производства добавленной стоимости. Ну и, конечно, систему оказания услуг, в первую очередь тех, что помогают производству добавленной стоимости. Хотя не меньшее значение имеют и услуги, облегчающие людям жизнь. Практика показывает, что их отсутствие в конечном счете весьма негативно влияет на производство добавленной стоимости.

Полностью вменяемые государства встречаются, увы, не так уж часто, но в классической системе свободного рыночного капитализма (свободного не в смысле «что хочу, то и ворочу», а в смысле свободной конкуренции и отсутствия нерыночных ограничений) имеется встроенный механизм, позволяющий сделать производство добавленной стоимости максимально эффективным. Этот простой механизм заключается в том, что не создающее добавленной стоимости и, как следствие, убыточное предприятие просто перестает существовать - со всеми вытекающими отсюда печальными последствиями для его владельцев и менеджеров. При этом другие, прибыльные, предприятия в своей совокупности обеспечивают прибыльность всей описанной выше системы создания добавленной стоимости.

Пока предприятия остаются достаточно простыми и небольшими, а связь их прибыльности с деятельностью отдельных работников - однозначной, перспектива перестать существовать выступает весьма мощным мотивирующим фактором для всемерного улучшения качественных и количественных показателей работы. Фактором, затрагивающим каждого работника.

С ростом сложности производства и размеров предприятий ситуация становится более замысловатой. Увеличение предприятия позволяет выигрывать за счет многих факторов, прежде всего за счет сокращения доли общезаводских расходов на единицу продукции и синергии, то есть взаимного дополнения одних видов деятельности другими. Однако по мере усложнения корпорации растут и трансакционные издержки (грубо говоря, расходы на управление). На каком-то этапе такие издержки начинают превосходить прибыль от синергии, и корпорация утрачивает эффективность.

Из теории бизнеса известно, что для каждой корпорации существуют некие оптимальные размеры. Но практика, как всегда, не во всем следует теории. Реально размеры корпораций обычно значительно 
превосходят оптимальную величину. Обусловлено это амбициями руководства, его желанием влиять на правительство (особенно в случае транснациональных корпораций) и другими нерыночными факторами. Корпорации становятся большими, забюрократизированными, в них появляется масса подразделений, не имеющих прямого отношения к производству. И связь прибыльности с деятельностью конкретных работников оказывается весьма размытой. Короче, если кто-то пристроит свою любовницу в небольшую пекарню отвечать за состав теста, а она «не в теме», то печальный итог наступит весьма скоро. А если ту же любовницу пристроить вторым референтом в отдел контроля степени влияния высокой клейковинности отдельных сортов пшеницы на вариабельность помольной партии в крупном мукомольном холдинге, то, скорее всего, никаких итогов никто и не заметит. Пока таких любовниц не станет слишком много. В последнем случае с холдингом случится то же самое, что и с небольшой пекарней.

Руководство крупных корпораций эту проблему полностью осознает. Существует целая наука о мотивации сотрудников, создаются специальные подразделения, призванные обеспечить повышение вклада каждого работника в прибыльность корпораций. Собственно, именно расходы на такую деятельность и составляют основную часть упомянутых выше трансакционных издержек. Но, к сожалению, ее эффективность не всегда бывает велика. Вообще, в процессе знакомства с крупными западными и транснациональными корпорациями - нефтегазовыми, автомобильными, банковскими и др. - я не раз с некоторой обалделостью обнаруживал, что чем больше корпорация, тем сильнее она напоминает бывший Советский Союз.

В то же время между западной корпорацией (или крупной частной компанией) и Советским Союзом есть фундаментальная разница. Западная производственная корпорация обычно является прибыльной, а следовательно, живет, пока производит добавленную стоимость, нужную ее клиентам. И хотя Норткот Паркинсон в своих знаменитых Законах утверждает, что, когда число работающих в корпорации превышает тысячу человек, она перестает нуждаться в связи с внешним миром, для западных корпораций это все-таки просто гипербола, позволяющая эффектно довести до абсурда ряд логических построений.

А вот Советский Союз буквальным образом представлял собой суперкорпорацию, в точном соответствии с утверждением сэра Норткота не нуждавшуюся в связи с внешним миром и замкнувшую внутри себя, за редкими исключениями, всю свою деятельность (как минимум экономическую). Практически все, что производилось внутри этой корпорации, там же и потреблялось. При этом встроенный механизм, способствующий максимально эффективному созданию добавленной стоимости, отсутствовал напрочь. Его заменяли другие механизмы, не менее жестко встроенные, но приводившие, увы, к совершенно иным результатам. Об этих механизмах я и хочу поговорить. 
Для начала напомню в общих чертах, как действовала экономика Советского Союза. Это была система практически тотального централизованного планирования, при которой в союзных и республиканских министерствах определялось не только то, что и в каких количествах будут производить предприятия страны, но и то, что эти предприятия будут потреблять в виде материалов и комплектующих. Существовали ограниченные лимиты и фонды на более или менее приличные материалы и комплектующие. Решали, кому что направить, чиновники внутри соответствующих отраслевых министерств.

Планирование осуществлялось по количеству и ассортименту (с упором на количество - знаменитый «план по валу») и велось по количественно согласованной схеме, то есть, если тебе нужно было выпустить 100 мотоциклов, ты получал чуть более ста двигателей (с запасом на процент брака), причем с определенного завода. Если вдруг имелся другой завод, по каким-то причинам выпускавший более качественные двигатели, чтобы их получить, ты был должен добиться выделения лимитов на них в Москве. Но такое дублирование было редкостью.

За перевыполнение (количественное) плана часто полагалась премия, то есть заводу позволяли разово увеличить на определенную сумму фонд заработной платы (часть средств, которую можно было выдать сотрудникам в виде наличных денег). Но поскольку планирование осуществлялось от достигнутого, руководство старалось не допускать значительного превышения предписанных показателей, ибо, произведя 102 мотоцикла вместо ста, ты рисковал на следующий год получить уже 102 мотоцикла в качестве планового задания. Так как фонд заработной платы при этом обычно не увеличивали, возникал резонный вопрос: а тебе это надо?

Из такой организации закономерно вытекали два следствия. Первое состояло в том, что инновации не только не приветствовались, но и активно подавлялись. И хотя официально декларировалась всяческая поддержка изобретателей, которым даже платили какие-то мелкие деньги, реальное положение дел отражал скорее термин «внедрить» рацпредложение или изобретение, подразумевавший, что само оно ну никак не пройдет, его надо силой проталкивать. И это была чистая правда.

Второе следствие - чрезвычайно низкий статус хороших специалистов-производственников. Совсем без них обойтись, конечно, было нельзя - ведь план по производству надо все-таки как-то выполнять, но гораздо важнее были люди, способные что-то достать для завода, добиться увеличения фонда заработной платы и т.п. Человек, у которого были знакомства в соответствующем министерстве в Москве, ценился на порядок выше классного специалиста в любом производстве. Ну а московские чиновники, от которых зависело решение всех этих вопросов, вообще находились на положении небожителей. 
Разумеется, многие понимали порочность такой системы. Постоянно велись разговоры о частичном хозрасчете, внедрении (опять внедрении!) материальной заинтересованности, ипатьевском методе и т.д. Однако все кончалось ничем. Причин называлось много, но попытки серьезного анализа обычно попахивали антисоветчиной и быстро сворачивались. КПСС, обладавшая политической властью в стране, рассматривала строго централизованное управление экономикой как идеологическую догму. Поэтому любая реальная инициатива снизу рано или поздно начинала восприниматься как попытка подрыва основ и жестко пресекалась.

Итак, в систему был встроен ряд негативных по своему воздействию механизмов. Во-первых, это торможение развития производства, прежде всего качественного (количественно развиваться можно по приказу сверху, построив, скажем, новый завод). Из него органически вытекало подавление всяческой инициативы, идущей снизу. Во-вторых, исчезновение мотивации к получению качественного профессионального образования и повышению квалификации. В-третьих, наделение незаслуженной и безответственной властью людей, причастных к распределению ресурсов. В условиях тотального дефицита эта власть не просто была очень значительной, но и зачастую, как, например, в системе торговли, приносила серьезные по тем временам материальные блага, становясь источником почти повсеместной криминализации.

Люди, помнящие те времена, помнят и следствия работы данных механизмов - жалкое состояние рынка потребительских товаров и услуг и гнетущее впечатление от продукции, производимой советской промышленностью. Однако главное заключалось даже не в этом. В стране постепенно складывалась система отношений, в которой распределение продукта было полностью оторвано от его производства. Этот отрыв носил в том числе и территориальный характер - распределение основной части продуктов и ресурсов происходило в Москве, производство осуществлялось по всей стране. Власть и блага сосредоточились в руках людей, с производством продуктов и ресурсов, а следовательно - и добавленной стоимости не связанных. Поскольку бюрократия воспроизводит сама себя и у всех этих людей были родственники, любовницы, друзья, которых надо было пристраивать, плодились отделы и подразделения министерств, возникали всякого рода проектные институты, неизвестно что проектировавшие, но имевшие громадные штаты сотрудников, и другие столь же «полезные» организации. Как это все отражалось на создании суммарной добавленной стоимости, наверно, понятно всем. Хотя выразить это в цифрах тоже представляло проблему - если количественная статистика как-то велась, индикаторов качественных изменений не было вообще.

Такое положение способствовало выработке довольно специфического мировоззрения, в котором на первый план выступали связи, знакомства, место в системе распределения. Каким образом появлялись 
распределяемые ресурсы, как бы оставалось за кадром, мало кого интересовало.

Заслуживает внимания и еще одно не очень очевидное, но крайне важное следствие. Инициатива снизу подавлялась везде - и в производстве, и в распределении. Но ввиду того что инициатива в производстве ничего кроме головной боли не приносила, она была уделом небольшой кучки энтузиастов. Инициатива же в распределении, будучи делом криминальным, приносила участникам неплохой материальный доход. Отсюда - активная криминализация данной сферы и формирование в ней навыков самоорганизации, к сожалению, изначально преступного толка. Группы людей, задействованных в сфере производства, такими навыками самоорганизации не обладали.

Описанная выше система не распространялась только на две сферы: производство продукции на экспорт и военную промышленность. Первая из них играла довольно скромную роль в советской экономике, и я не буду на ней останавливаться. Напротив, место второй, неразрывно связанной с ядерной, авиационно-космической, судостроительной промышленностью и рядом других мощных отраслей, было весьма велико, и о ней стоит поговорить подробнее.

Поскольку высшее руководство страны, пребывавшее в постоянной конфронтации с Западом, прекрасно понимало, что его шансы на успех напрямую зависят от наличия эффективного оружия, сфера производства вооружений находилась под особым контролем. Она обладала абсолютным приоритетом в смысле получения любых ресурсов. И ей приходилось реально конкурировать с военной промышленностью Запада: объяснения типа того, что советские ракеты хуже западных, так как у социалистической экономики есть более важные цели, обычно использовавшиеся для оправдания низкого качества товаров народного потребления, здесь выглядели неуместно.

В этой сфере существовала так называемая внутриотраслевая конкуренция, когда одной и той же задачей параллельно занимались несколько коллективов, объединявших в себе научные институты, конструкторские бюро и заводы (коллективы Челомея, Макеева, Королева в космической промышленности, Туполева, Микояна и Гуревича, Ильюшина, Сухого - в авиационной и т.д.). И для того чтобы новый аппарат приняли на вооружение, он должен был отвечать лучшим мировым образцам и превосходить сделанное конкурентом. Конкуренция по принципу «я через знакомых достану нужные радиодетали, а моему конкуренту их не дадут» не проходила. Сотрудник министерства, не давший их конкуренту, имел все шансы угодить под расстрельную статью, особенно если выяснялось, что это плохо повлияло на обороноспособность страны, а проектом заведовал какой-нибудь известный гуманист вроде Л.П.Берия. Поэтому на первый план выдвигались грамотные специалисты, понимавшие в своем деле. Они, а не пробивные снабженцы были ключевыми фигурами в создании военной техники. Конечно, связи в Москве влияли на принятие различных решений, но все-таки это влия- 
ние было ограниченным. Эпопея с созданием (не без помощи разведки) советской атомной бомбы принесла понимание того, насколько важна для развития военной техники фундаментальная наука, и в стране появилась весьма пристойная система подготовки кадров в области естественных наук. Некоторые утверждают, что она была лучшей в мире. В силу ряда обстоятельств (посмотрите, например, на состав нобелевских лауреатов по физике и химии) говорить о полном превосходстве, видимо, не очень корректно, но система показала себя вполне конкурентоспособной. Возникла сеть научных и проектных учреждений, опиравшихся на академические институты и нацеленных на практические результаты. Часть этих практических результатов (летавших, плававших, стрелявших) действительно превосходила зарубежные аналоги. И, наверное, это была единственная сфера деятельности в Советском Союзе, где человек мог выдвинуться за счет собственного ума и профессиональных качеств, а не за счет связей или выстраивания отношений с начальством.

Правда, и здесь имелась собственная специфика. В отличие от Запада, где военные заказы государства выполнялись крупными корпорациями, ведущими активную деятельность и на гражданском рынке, советская военная промышленность была полностью сориентирована на оборонный заказ (плановые задания по производству каких-нибудь титановых кастрюль не в счет). Вопросы, касающиеся стоимости продукции, тут никого особенно не волновали. Разумеется, какие-то расчеты себестоимости производились, но они носили преимущественно декоративный характер. В результате производство оказывалось очень дорогим, что препятствовало использованию соответствующих наработок в гражданских отраслях.

В силу своего режимного характера военная промышленность была менее подвержена криминализации, нежели гражданская. И хотя во времена так называемого застоя туда тоже стали проникать разного рода негативные тенденции, в частности воровство с предприятий, масштабы распространения там подобных практик были несравнимы с тем, что происходило в гражданском секторе.

По мере утраты КПСС способности реально управлять государством (а началось это не в конце 1980-х годов, но гораздо раньше) средние и низовые уровни власти все больше криминализировались. В первых рядах шла система распределения. Поскольку свободное обращение имели исключительно наличные деньги, получить которые можно было главным образом от населения, сферы, связанные с торговлей потребительскими товарами и предоставлением услуг, криминализовались практически на сто процентов. Малопрестижные на Западе профессии бармена и официанта приобрели зловещий, но денежный оттенок. А директор ресторана или магазина, хотел он того или нет, неминуемо оказывался членом какой-то криминальной сети. Интересно, что большинство влиятельных питерских «авторитетов» времен перестройки вышло именно из этой среды.

“ПОМПTHЯ” № 7 (56) 2010 
В результате к концу 1980-х годов экономика страны выглядела следующим образом. Промышленность, призванная удовлетворять потребительский спрос населения, выпускала неконкурентоспособную на мировом рынке продукцию. Новые виды продукции, по сути, не разрабатывались; если что-то новое и производилось, то по технологиям и на оборудовании (отнюдь не самых последних образцов), закупленном на Западе. Но даже такая продукция была в дефиците и, попадая в коррумпированную систему распределения, позволяла получать криминальный доход. Квалификация технических специалистов, занятых в производстве товаров народного потребления, мягко говоря, оставляла желать лучшего, стимулы к ее повышению отсутствовали. Чрезвычайно низкой была и мотивация работников, разгильдяйство и брак превратились чуть ли не в норму. Сложилось странное отношение к заводскому имуществу, когда кража продукции и материалов не только не рассматривалась как преступление, но и воспринималась как благое дело: «приберу-ка я это себе, а то сгниет». Сфера услуг и торговля были полностью криминализованными и абсолютно безобразными с точки зрения качества и отношения к клиентам.

Об аграрном секторе не хочется даже и говорить. Все, кто застал выезды горожан на сельхозработы, видели все своими глазами.

Базовые отрасли тяжелой промышленности, такие как, скажем, металлургия, были технически отсталыми и крайне громоздкими и неповоротливыми. Продукции выпускалось много, но доля высококачественной номенклатуры была очень невелика. Например, в той же металлургии на высококачественную легированную сталь приходилось не более $10 \%$ общего объема производства.

В несопоставимо лучшем положении находились отрасли, непосредственно работавшие на оборону (самолето-, судо- и танкостроение, космическая, атомная и некоторые другие виды промышленности). В этих отраслях продолжала разрабатываться новая техника, сохранялись научные школы и система подготовки кадров. И создаваемая там продукция соответствовала лучшим мировым образцам, иногда даже обгоняя их. Не случайно даже сейчас, в начале XXI в., успешно продаются военные разработки 1980-х годов (в 1990-х в промышленных масштабах не разрабатывалось уже практически ничего). Конечно, экономическая эффективность данных отраслей, судя по всему, была далека от идеала, но несколько лет целенаправленных усилий все могли бы поставить на свои места. В сложных высокотехнологичных отраслях гораздо легче организовать эффективный менеджмент на базе существующего производства, нежели наоборот.

Технологический потенциал этих отраслей мог бы быть дополнен развитием перерабатывающей промышленности - металлургии, нефтехимии и т.п. Держа в руках источники сырья, можно было обеспечить его дальнейшую переработку, создавая бо́льшую часть добавленной стоимости внутри страны, и, используя эти ключевые компетенции, плавно перевести ее на рыночные рельсы, не теряя, а, наоборот, совер- 
шенствуя высокотехнологичное производство. Для этого нужна была самая малость: политическая воля, рычаги управления страной и понимание того, в каком направлении двигаться.

Однако и с политической волей, и с рычагами управления, и с пониманием направления движения дело обстояло крайне печально. Криминализация власти в регионах постепенно сводила на нет реальное влияние Москвы. Завязшая в Афганистане армия также криминализировалась. Возможность держать руку на вентилях каналов распределения того, что производила и получала от внешней торговли страна, могла безвозвратно уйти. В этой ситуации, похоже, центральная власть решилась на сдачу своих позиций Западу в обмен на кредитные вливания, которые распределяла именно она. Размер этих кредитных вливаний довольно мутная материя, поскольку информация о величине долга СССР, унаследованного РФ, противоречива, но, по подсчетам экспертов, за 1990-е годы (до 1998 г.) он вырос примерно на 60 млрд. долларов (не считая ГКО-ОФЗ). Для реального развития такой страны, как Россия, этого, скорее всего, было мало, но для обогащения клана, стоящего у власти, - более чем достаточно.

В условиях высокой инфляции и ограниченности круга лиц, допущенных к участию в импортных операциях, доступ к кредитам ЦБ и конвертации рублей в доллары позволял делать деньги из воздуха, только за счет отставания роста ставки рефинансирования от процента инфляции. Можно было взять межбанковский рублевый кредит, конвертировать его в доллары, на доллары купить, скажем, компьютеры, продать их с рентабельностью в $100 \%$ плюс инфляция, часть денег отдать ЦБ, вернув кредит и соблюдя видимость законной сделки (я подозреваю, что в реальности даже этого не делали), оставшуюся часть обменять на доллары, используя то обстоятельство, что курс устанавливался государством и еще больше отставал от инфляции, и т.д. На фоне этой халявы все финансовые пирамиды, операции с чеченскими авизо и другие известные аферы тех лет выглядят жалкими потугами дилетантовнеудачников.

Но чтобы воспользоваться этим механизмом, требовался доступ к валюте, поступавшей из-за рубежа в виде кредитов. Не обладавшие им региональные мафии чувствовали себя обделенными. Тогда началось разворовывание и распродажа всех реальных активов, накопленных в Советском Союзе.

В начале 1990-х годов в Петербурге в течение месяца были ограблены склады редких металлов сразу нескольких оборонных заводов ночью к стене завода подгонялся кран типа «Като» или «Ивановца» с выдвижной стрелой и через стену переносилось все содержимое склада. На гражданских предприятиях разворовывание осуществлялось с помощью разного рода аффилированных фирм, управляемых родственни- 
ками руководства. Сбор лома цветных металлов полностью монополизировали криминальные структуры, и в лом сдавали все, вплоть до силовых кабелей. В середине 1990-х годов «независимая» Эстония оказалась одним из крупнейших экспортеров цветных и редких металлов в мире, хотя новых медных или никелевых рудников в районе Таллинна вроде бы открыто не было.

В Советском Союзе была создана одна из лучших в мире систем генерации и распределения электроэнергии. Ввиду отсутствия достаточного числа международных линий электропередач продавать электроэнергию за границу было сложно, поэтому продавали продукцию, для производства которой требовались большие затраты электроэнергии, в частности алюминий. Организация производства алюминия по толлинговой модели, по сути, являлась экспортом овеществленной электроэнергии, получаемой по тарифам, значительно более низким, нежели за границей.

Как уже говорилось, способность к самоорганизации людей, занятых на производстве, в Советском Союзе оказалась практически полностью подавленной. С самоорганизацией же разнообразных криминальных и полукриминальных групп в сфере распределения дело обстояло гораздо лучше. Именно такого рода криминальные «распределенцы» и захватили промышленные предприятия. Обычно это происходило по самой примитивной схеме - зятьями и сватьями генерального директора создавалась фирма-«прокладка», которая торговала продукцией завода и/или поставляла на него сырье. Продукция приобреталась по заниженной цене, сырье поставлялось по завышенной, а убытки вешались на завод. Когда эта ситуация стала повсеместной и налоговая инспекция с валютным контролем начали с ней бороться, схемы усложнились, но суть осталась той же. Часто заводы вставали. Для сотрудников завода это было трагедией, для «распределенцев» - эпизодом. На предприятии, где могла работать тысяча человек, хватало активов, чтобы за счет их продажи обеспечить безбедное существование двум десяткам приспешников руководства, их чадам и домочадцам. Работающий завод, правда, обеспечивал еще тысячу человек, но подобные мелочи мало кого волновали. Это директор ядерного центра в Снежинске академик Владимир Нечай застрелился от стыда за бессилие организовать своим подчиненным нормальную жизнь. Другие спокойно воровали и не стрелялись.

К моменту начала приватизации подобные группы «распределенцев» и оказались основными претендентами на место «эффективного собственника». Правда, если они не входили в какой-либо крупный криминально-номенклатурный клан регионального уровня, а один из таких кланов интересовался заводом, их претензии могли закончиться летальным исходом. Но заводу от этого легче не становилось.

Все это сопровождалось невиданной криминализацией общества. Собственно, сращивание государственно-партийного аппарата с уголовным миром активно шло и в советские времена, но в эпоху пере- 
стройки криминализация приобрела всеобъемлющий характер. Криминальные структуры использовались практически всеми кланами старой номенклатуры и спецслужб, поэтому других сил, действующих на местах, в «экономике переходного периода» в общем-то и не было. Мораль большей части советского народа была хорошо подготовлена к такому повороту событий, и по крайней мере в начале кооперативного движения рэкетиры воспринимались многими как своего рода Робин Гуды. Потом уровень романтизации несколько снизился, но в первой половине 1990-х годов я сам с некоторой оторопью наблюдал, как воров в законе представляли чуть ли не спасителями общества. У бандитов брали интервью, по телевизору с придыханием говорили об их пожертвованиях на церковь и благотворительность. Был анекдотичный случай, когда реальный питерский вор в законе, «специалист» по антиквариату, дал интервью, в котором на полном серьезе предупреждал общество, что так нельзя, что воров не должно быть много, ибо, если кроме воров никого не останется, наступит беспредел и всем придет хана. Умный был человек, мир его праху (умер в тюремной больнице «Крестов», потом послужил прототипом Барона, персонажа «Бандитского Петербурга»), понимал паразитический и антисистемный характер криминального мира, хоть и вор. К сожалению, большинство граждан такими аналитическими способностями не обладало.

Я не знаю, насколько сильным было влияние такой криминализации на поколение, психика которого формировалась в тот период, но подозреваю, что значительным. Вообще говоря, термин «криминализация» не совсем адекватно отражает происходившее. Криминализация это когда количество криминальных элементов начинает заметно увеличивается. А ситуация, когда эти элементы навязывают обществу свою волю, правила и порядки, называется по-другому - криминальный террор. И последствия этого террора, поддерживаемого и используемого так называемыми «элитами», будут сказываться на процессах, развертывающихся в нашем обществе, еще долгое время.

Поскольку номенклатурные кланы, в которые входили криминальные группы, расплачивались с этими группами прежде всего предоставлением им возможности «стричь» бизнесменов на определенной территории, очень быстро сложилась ситуация, когда вести свой бизнес мог только тот, кто платил какой-либо криминальной группе за «крышу» или обладал связями во властных кругах (в последнем случае платить обычно тоже приходилось, но криминальная группа уже вела себя с тобой более осторожно). Поэтому перед человеком порядочным, peшившим заняться бизнесом, вставал дополнительный психологический барьер, часто непреодолимый. Это создавало еще один механизм негативной селекции.

К середине 1990-х годов центральная власть осознала, что в процессе приватизации утрачивает контроль над важными активами, и организовала известные залоговые аукционы, в результате которых все крупные нефтегазовые компании, Новолипецкий металлургический 
комбинат, бо́льшая часть пароходств и ряд важных сырьевых фирм попали в руки нужных людей, образовавших впоследствии группу так называемых «олигархов». Наверно, это было началом понимания того, что в нынешних условиях власть может зарабатывать для себя громадные деньги лишь с помощью распределения преференций или постановки шлагбаума в нужном месте и взимания денег за проезд. Не то чтобы она не делала этого раньше, просто масштабы существенно изменились. Особенно ясно это стало после того, как цена на нефть выросла с 14 долларов за баррель в 1994 г. до 24 в 1996-1997 гг. Получаемая прибыль, конечно, не шла ни в какое сравнение с той, которую приносила нефть после 2003 г., но ведь с чего-то надо было начать.

Инфляция, превышавшая $100 \%$, делала бессмысленным скольконибудь долгосрочное кредитование даже оборотного капитала в промышленности, не говоря уже о кредитовании капитальных вложений. Поэтому в первой половине и середине 1990-х годов из реальной банковской деятельности банки занимались только кредитованием краткосрочных торговых сделок. Все остальное было основано на использовании отставания ставки рефинансирования от реального уровня инфляции и доступа к валютным ресурсам либо сводилось к накоплению капитала того или иного клана и использованию его для концентрации в руках этого клана неких активов. Банки поменьше были, по сути, просто общаками криминальных групп. Бурным цветом расцвели разного рода брокерские конторы и чековые фонды, торговавшие акциями приватизированных предприятий и разными мутными бумагами типа «акций» МММ, «Тибета» и т.п. Из того периода мне больше всего запомнилась реклама акций «Токур-Золота»: на экране телевизора демонстрировался кусок карты России, охватывающий половину Восточной Сибири, и под мотив «Коробочки» пелся следующий текст:

\footnotetext{
«Где-то тут нашли мы золото,

Много золота - завались!

Токур-Золото, Токур-Золото,

Покупай же, не скупись!»
}

Реклама подкупала своим веселым цинизмом, но реакция на нее населения удручала до крайности. Я замучался объяснять своим знакомым, что для выплаты акционеру 600\% годовых деятельность компании должна приносить ей как минимум чуточку больше, а такой прибыли не дает даже наркоторговля, если учесть все трансакционные издержки.

Торговля акциями реальных предприятий имела, конечно, больше смысла, по крайней мере в долгосрочной перспективе, однако если бы люди знали, в каком состоянии обычно находился реестр акционеров, и представляли себе положение дел на предприятиях, у большинства бы, наверное, пропало желание их покупать (я говорю не о кланах, аккумулирующих активы, а о людях, пытающихся что-то заработать или спасти свои деньги от инфляции). 
Поскольку валюты, получаемой из-за рубежа в форме кредитов, по-видимому, не хватало на всех заинтересованных, все более активно муссировалась тема ГКО-ОФЗ. В принципе любое правительство прибегает к выпуску облигаций, которые обычно являются самыми надежными и вместе с тем самыми низкодоходными бумагами на рынке ценных бумаг. Средства, полученные от размещения таких облигаций, государство использует для реализации своих проектов, от совокупного выполнения которых надеется когда-нибудь получить вложенную сумму плюс некий небольшой процент прибыли, который выплачивается держателям. Как правило, это не более 5\% годовых. Доходы же по операциям с ГКО зашкаливали за 100\%, причем с середины 1995 г. на рынок ГКО пустили нерезидентов, и пусть не сотни, а десятки процентов можно стало получать в валюте. Нерезидентов, впрочем, пустили не всех, а особо приближенных. Подозреваю, что большинство их составляли компании, управляемые через подставных лиц коррумпированными чиновниками и игравшие деньгами, перед этим выведенными из России. Среди них, правда, были и такие люди, как Джордж Сорос, которым все-таки едва ли управляли коррумпированные чиновники, однако, по его собственному признанию, после дефолта он потерял на ГКО пару десятков то ли миллионов, то ли миллиардов (коррумпированные чиновники денег не теряли). Прошу простить мне некоторый цинизм, но я лично сталкивался, например, с тем, что банки приобретали ГКО на бюджетные деньги, находящиеся на их счетах, то есть давали государству в долг его же деньги. Грубо говоря, это примерно эквивалентно ситуации, когда вы берете у человека 100 рублей, даете их ему в долг под $100 \%$ - и через год не вы ему должны 100 рублей, а он вам. Понятно, что при попытке провернуть такую операцию с конкретным человеком вас пошлют по известному адресу, если не хуже. Государство почему-то не посылало. Все помнят, чем это закончилось в 1998 г.

После дефолта, когда курс рубля упал в несколько раз, казалось, появились некоторые признаки выздоровления. Началось массовое импортозамещение, в первую очередь коснувшееся продуктов питания. Предприятия, производившие такие продукты, значительно увеличили свои продажи. Позднее в этот процесс включились и производители промышленной продукции. Те, кто немного думал о будущем, использовали увеличившийся денежный поток для расширения своих предприятий, их модернизации или хотя бы капитального ремонта изношенного оборудования. Таких, увы, было меньшинство, но они были, прежде всего среди производителей пищевой продукции, где модернизация обычно сводилась к закупке импортных автоматических или полуавтоматических линий, позволявших при наличии необходимых сырьевых компонентов производить качественную продукцию, то есть представляла собой относительно несложную с технологической точки зрения задачу. Были успехи и в некоторых других отраслях. Вообще, если бы в тот момент кто-то всерьез взялся за возрождение национального промышленного производства, результаты, наверное, оказались 
бы гораздо более значительными. Однако, как видно, в стране уже не было ни людей, способных поставить такую цель, ни тех, кто бы мог ее реализовать. «Распределенцы», особенно управляющие крупными заводами, восприняли происходящее как свалившуюся с неба возможность увеличить свои доходы, чем и занялись с большим энтузиазмом. К тому же к концу 2000 г. цена на нефть поднялась выше 30 долларов за баррель, а с начала 2003-го стабильно пошла вверх, и государство, похоже, бросило все, кроме передела нефтяных и газовых активов.

Надувание пузыря нефтяных цен, начавшееся в 2003 г., привело к окончательному формированию той «экономики распределения», с которой Россия встретила мировой кризис. «Распределенцы» получили источник валютных доходов, который позволял им не только безбедно существовать, но и делиться с частью населения страны, преимущественно с жителями крупных городов. На определенном этапе денег стало даже слишком много, и их стали складывать в стабилизационный фонд, образованный в 2004 г. К сожалению, воздействие этих денег на российскую экономику мало чем отличалось от воздействия наркотика на ракового больного - они создавали иллюзию благополучия, в то время как организм продолжал разрушаться.

Система, сложившаяся в последние предкризисные годы, сводилась к следующему. В страну попадали очень большие деньги, полученные за экспорт углеводородов (и другого сырья тоже, но ключевое значение имели углеводороды). Эти деньги делились на два потока: один шел в бюджет, другой - в доходы сырьевых и трейдинговых компаний. Затем эти деньги распределялись дальше и использовались на вознаграждение лиц, обеспечивавших их движение, покрытие бюджетных расходов и импорт потребительских товаров (главным образом из Китая и Турции), продуктов питания, легковых автомобилей и т.п. Распределение осуществлялось в основном в Москве. Что касается бюджетных денег, то они распределялись по «своим» компаниям, обеспечивающим «распределителям» максимальный процент «отката» и максимальную безопасность его получения. Размер «откатов» доходил до $50 \%$ суммы при финансировании научных проектов, где результата вообще могло не быть, и 40\% в конкретных проектах, например в дорожном строительстве. Качество построенных дорог при этом, разумеется, никого не интересовало.

Деньги сырьевых и трейдинговых компаний также направлялись исключительно в «свои» компании, либо являвшиеся прямыми «дочками», либо принадлежавшие зятьям и сватьям менеджеров разного уровня, причастных к распределению заказов. Довольно большая часть денег выводилась из страны и тратилась на покупку недвижимости, яхт и других атрибутов шикарной жизни. Немало денег уходило на офисы, автомобили, жилье и услуги в Москве. 
При всем этом разгуле потребления на капитальные вложения даже в ключевую нефтегазовую область расходовалось до неприличия мало. В 2004 г. (год образования стабилизационного фонда) недофинансирование капитальных вложений в нефтяную индустрию официально оценивалось в 20 млрд. долларов. На самом деле эта цифра, скорее всего, была в несколько раз больше. Геологоразведка новых месторождений практически не проводилась вообще. Производство оборудования для нефтегазовой промышленности находилось (за некоторыми исключениями) в плачевном состоянии и на уровне двадцатилетней давности. При поставках оборудования в нефтяные и газовые компании широко практиковалась та же схема «откатов». Часто оборудование приобреталось по специально завышенным ценам, и разница в цене возвращалась обратно в виде «отката». Один сотрудник «Газпрома» уверял меня, что эта практика внесла немалый вклад в увеличение себестоимости российских газа и нефти, так как завышенная цена оборудования приводила к увеличению амортизации, включаемой в себестоимость.

Можно сказать, что сложившаяся система представляла собой материализовавшуюся голубую мечту «распределенцев». По сравнению с ней тот же Советский Союз выглядел верхом промышленной целесообразности и торжества закона - там иногда даже сажали за воровство государственных средств, возникали дела Трегубова, Медунова и др. Нынешнюю же ситуацию лучше всего характеризуют два популярных анекдота. В первом из них неудавшийся бизнесмен встречает своего школьного товарища, занимающего какой-то пост, и тот предлагает ему совместный бизнес, заключающийся в том, что бизнесмена сажают в комнате с дверцей и ручкой на веревочке и он каждый день дергает за эту ручку, после чего дверца открывается и из нее сыплются деньги. В конце месяца бизнесмен половину собранных денег относит товаришу, половину оставляет себе. Сначала все идет хорошо, но потом жена бизнесмена замечает, что тот ходит мрачный, пригорюнившийся На вопрос, что случилось, он отвечает: «Ну как же, вкалываешь тут всю жизнь как проклятый, а половину заработанного каждый месяц приходится отдавать какому-то дармоеду». Так вот, абсолютное большинство фирм, зарабатывавших основные деньги в «экономике распределения», действовало полностью по этой схеме. Внешний антураж соблюдался как надо - имелись сотрудники, бухгалтерия, офис в бизнес-центре класса А, Мерседесы и Порше Кайены с шоферами, чего-то даже делалось. А на самом деле была дверца в стене и ручка на веревочке. И половина суммы какому-то нужному партнеру. Заниматься производством добавленной стоимости в такой экономике было как-то не очень прилично.

Во втором анекдоте описывается, как молодой судья пришел к старому с вопросом, что ему делать в сложной ситуации, когда одна сторона принесла 20 тыс. долларов, а вторая - 25. Старый судья посоветовал отдать второй стороне 5 тыс. обратно и судить по справедливос- 
ти. Этот анекдот, как и первый, очень точно отражает положение в стране в тот период. Если в начале 1990-х годов за всякие мыслимые пределы зашкаливал криминал, то в начале «нулевых» за всякие мыслимые пределы зашкалила коррупция в государственных органах и силовых структурах. Так называемый процесс «усиления государства», якобы наблюдавшийся в это время, на самом деле означал лишь то, что роль криминальных структур окончательно перешла к государственным органам. Когда справедливо говорили об усилении коррупции в стране, упускали из виду, что коррупции в России не просто больше, чем в развитых капиталистических странах, - она качественно другая. В европейской стране государственный чиновник тратит основную энергию на выполнение своих служебных обязанностей и иногда может позволить себе сходить в ресторан за счет дружественной строительной фирмы или втихаря пристроить родственника на теплое место. В России же государственный чиновник сейчас тратит основную энергию на обслуживание интересов того, кто протолкнул его на эту должность, и только иногда, чтобы не возникало совсем уж неприличных ситуаций, имитирует выполнение государственных обязанностей. И при этом, конечно, не забывает о собственных «интересах».

На базе коррупции в правоохранительных и судебных органах возникла целая индустрия рейдерства, то есть отъема предприятий у их владельцев. Предприятие можно было отнять у любого, все зависело от связей во властных структурах.

Коррупционные отношения постепенно начинали восприниматься как нечто нормальное. Выросло поколение людей, которые вообще не представляют, как может быть иначе. Такие понятия, как «административный ресурс», «фонд организационно-консультационных расходов» и т.п., стали практически официальными.

Избыток шальных денег, а также нежелание и неумение вкладывать их в промышленное производство привели к тому, что в стране начался бум недвижимости. Всем казалось, что недвижимость - это самый простой и надежный объект для инвестиций: построил здание и получай доход, не то что изготовление каких-нибудь компьютерных плат - там надо разбираться и в компьютерах, и в бизнесе, да и вообще возни много. Такая мелочь, как наличие желающих жить или работать в построенных зданиях и имеющих возможность за это платить, никого не волновала, так как во всех сферах жилой и коммерческой недвижимости наблюдался сильнейший дефицит по сравнению с развитыми европейскими странами, а увеличивавшееся количество денег стимулировало рост цен и на объекты недвижимости, и на землю. Поскольку основные «ручки на веревочке» находились в Москве, в первую очередь зашкалили московские цены. Потом за ними потянулись цены в Питере и крупных региональных центрах. Городские чиновники радостно включились в этот праздник жизни - коррупция в сфере распределения участков и получения разрешительных документов на строительство также зашкалила. 
В третьем квартале 2008 г. вся эта благодать стала рушиться. Сначала в Америке разразился так называемый ипотечный кризис, потом закувыркались биржевые котировки, а потом рухнули цены на нефть. Можно долго и интересно обсуждать причины мирового кризиса, роль эмиссии необеспеченных долларов, фьючерсных пузырей на сырьевых рынках и т.п., но для России главным было другое - обвал цен на нефть. «Экономика распределения» вдруг обнаружила, что распределяемого скоро перестанет хватать не то что на всех, но даже на меньшинство.

В первые месяцы кризиса мне попадалось много всяких оригинальных высказываний относительно влияния мирового кризиса на Россию, из которых особенно запомнились следующие два: мировой кризис мало затронет Россию, потому что у нас слабо развита система ипотечного кредитования; мировой кризис мало затронет Россию, потому что на бирже котируется небольшое число российских предприятий и биржевые обвалы касаются малой части экономики. Другие мнения также сводились к тому, что ситуация в России будет отличаться от западной - и почему-то в лучшую сторону. А когда цена на нефть подтянулась к 80 долларам за баррель и первый испуг немного ослаб, зазвучали разговоры о том, что кризис заканчивается, в 2010 г. начнется подъем и все будет хорошо.

Я не сомневаюсь, что кризис в России будет иметь собственную специфику, но не верю, что кому-то покажется мало и все скоро кончится, как пытаются сейчас уверить себя и окружающих официальные спикеры. Кризис в России действительно будет серьезно отличаться от западного. Там есть свои, и достаточно сложные, проблемы, но западный кризис в его основе - это кризис финансовой системы. Во-первых, после отказа от золотого обеспечения навыпускали огромное количество необеспеченных долларов, которые стали накапливаться во всяких ключевых местах вроде цен на недвижимость, нефтяных фьючерсов, супердешевых и необеспеченных кредитов, биржевых спекуляций и т.п. Во-вторых, расплодили громадное количество деривативов, превратив финансовый рынок из механизма перераспределения денег в пользу более эффективных отраслей в некое подобие гигантского казино. Одним из следствий такого положения вещей, особенно касающимся CDS-деривативов, стало размывание ответственности банков за свои решения. Система классической капиталистической экономики представляет собой своего рода корабль, отсеками которого являются отдельные компании, банки и т.п. Если банк наделал глупостей и пробил дыру в борту своего отсека, то отсек быстро заполнится водой со всеми вытекающими отсюда последствиями для там находящихся, но водонепроницаемые перегородки между отсеками не позволят воде затопить весь корабль. Кредитов хочется давать как можно больше (банк на этом зарабатывает), но тонуть в случае неудачи не хочется совсем. 
CDS-деривативы позволили распределить риски дефолта кредитов одного банка на множество других финансовых структур. Это оказалось эквивалентно проделыванию дырок в водонепроницаемых перегородках. Вода рассредоточивалась по многим отсекам, и до поры до времени всем было хорошо. Когда же начало сильно мочить ноги, спохватились, но вода уже заполнила весь корабль.

Однако система производства добавленной стоимости в реальной экономике при этом продолжала действовать. Велись разработки высокотехнологичной продукции, создавались новые автомобили и устройства, новые станки и обрабатывающие центры, подготавливались кадры, работали научные школы. Корпорации «Делл», IВМ, НР, 3М, «Дженерал Электрик», «Боинг» и т.д. никуда не исчезли. Никуда не исчезла военная промышленность США и Европы. Никуда не исчезли западные бренды - ни на потребительском рынке, ни на рынке высоких технологий. Да, довольно большая часть трудозатратных производств была выведена в Китай (о чем, между прочим, сейчас уже сильно жалеют), но ядро высокотехнологичной промышленности осталось на своем месте.

Компании реальной экономики, конечно, испытывают серьезные трудности, связанные с падением спроса, увеличением цены капитала и другими радостями кризиса. Однако кончится это тем, что сменится часть владельцев и акционеров, кто-то обанкротится, Уоррен Баффет купит солидный кусок «Дженерал Электрик» и т.д. и т.п., а система создания добавленной стоимости останется в целости и сохранности, и реальная экономика будет исправно производить свою продукцию, в том числе, кстати, и бомбардировщики «Стелс» с ракетами «Томагавк» или что там они еще придумали за последнее время. Да, спекулянтов деривативами станет, наверное, заметно меньше, но об этом вряд ли ктонибудь пожалеет, кроме их самих.

Что же касается России, то я не просто так пытался отследить историю нашей экономики со времен Советского Союза, рискуя вызвать недовольство читателей некоторой растянутостью повествования. Дело в том, что мне совсем не хочется делать те выводы, которые приходится делать. А выводы эти состоят в следующем. Все мировые достижения Советского Союза, на которых основана как вполне уместная для его жителей гордость за свою страну, так и абсолютно неуместное приписывание этих достижений существовавшей политической системе, были связаны с военной промышленностью, прежде всего в ее высокотехнологичной части. Это и первый космонавт, и луноход, и научные школы в области естественных и технических наук, и авиация, и флот с экранопланами, и многое-многое другое. Все остальное было, мягко говоря, не очень, хотя весомые достижения имелись и в других областях (в частности, в Советском Союзе было проведено первое направленное бурение, являющееся сейчас основой нефтедобычи). Эффективная система производства добавленной стоимости отсутствовала как в гражданской, так и в военной промышленности, однако на базе военной 
промышленности ее вполне можно было создать. Но за 20 с лишним лет, прошедших с момента принятия закона о кооперации, который можно считать началом перестройки, она так и не была создана - ни на базе военной промышленности, ни на какой-либо другой. Более того, за указанный период высокотехнологичная часть военной промышленности развалилась или близка к развалу, а у высокотехнологичной (да даже и не высокотехнологичной) системы производства добавленной стоимости в гражданской промышленности не было никаких шансов появиться.

Тот рост биржевых котировок, который наблюдался в последние несколько лет и служил почвой для бравурных официальных реляций и самоуспокоенности большинства населения, особенно той его части, которая не привыкла задумываться о природе вещей, был основан только на одном факторе - росте цен на нефть. Нефтяные деньги позволяли функционировать «экономике распределения», поднимали вверх котировки российских акций (как же - нефтедобывающая страна!), привлекали в страну спекулятивные капиталы, стимулировали строительство новых торговых и бизнес-центров. Любые попытки разумных людей обратить внимание на то, что ситуация с нефтяными ценами ненормальна и не может продолжаться вечно, тонули в стройном хоре голосов, доказывавших, что все отлично и будет так всегда: спрос на нефть растет, запасы уменьшаются, на арену выходит Китай и т.д. Хотя давно было видно невооруженным глазом, что цена на нефть колеблется обратно колебаниям курса доллара, что количество хеджеров и спекулянтов на рынке нефтяных фьючерсов в десятки раз превышает количество потребителей, реально нуждающихся в нефти, и в общем-то многое другое. Когда в конце 2008 г. в преддверии холодной зимы, когда спрос на нефть обычно растет, нефтяные цены в одночасье рухнули в три раза, стало ясно, что механизм их роста определялся отнюдь не реальным увеличением спроса, а какими-то другими факторами, прежде всего закономерностями фьючерсного рынка, да и, осмелюсь предположить, манипулированием таковым.

Для стран с более или менее разумным управлением периоды, когда деньги сыплются ниоткуда, являются Богом данной возможностью упрочить свое положение и решить какие-то назревшие экономические проблемы. Как правило, избыток денег вкладывается в инфраструктуру страны - отрасль, имеющую максимальные сроки окупаемости вложенных средств и потому не очень любимую частным капиталом, однако абсолютно необходимую для последующих инвестиций. Так, строительство любой железной дороги дает жизнь десяткам и сотням бизнес-проектов, строительство электрических и локальных газовых сетей позволяет строить коттеджные поселки и новые объекты промышленности и т.п. Россия же самым бездарным образом профукала эту возможность. Что касается стабилизационного фонда, то о нем лучше забыть: во-первых, потому, что за короткое время в начале кризиса уже спустили на поддержку рубля, то есть коту под хвост, свыше 
100 млрд. долларов, а во-вторых, потому, что корпоративный долг российских крупных (читай - государственных) компаний западным банкам составляет сумму, примерно равную размеру этого фонда. В случае дефолта по этим долгам, а он практически неизбежен, государству придется направить эти деньги на то, чтобы не допустить перехода стратегических активов в руки иностранцев. Да и ценность западных бумаг, в которых размещен стабилизационный фонд, сейчас становится все более и более сомнительной.

На сегодняшний день мы имеем полуразвалившуюся инфраструктуру, бо́льшая часть которой унаследована от советских времен, промышленное оборудование с физической амортизацией в среднем более $50 \%$ и почти полное отсутствие высокотехнологичного производства. Мы имеем полуразвалившуюся военную промышленность и полностью развалившуюся систему подготовки кадров для нее. По оценкам экспертов, только $15 \%$ российских предприятий работают в условиях рыночной экономики. В свете вышесказанного это означает, что только $15 \%$ российских предприятий как-то создают добавленную стоимость, в остальных же дергают за ручку на веревочке и собирают деньги. Примерно таков же и процент менеджеров, которые хоть что-то понимают в реальном управлении компаниями. Мы имеем почти полностью развалившуюся армию; победа над страшным врагом - грузинскими войсками все-таки, наверное, не должна внушать ложных иллюзий. А борьба за контроль над природными ресурсами обостряется, и Россия, которой принадлежит значительная часть мировых запасов углеводородов и пресной воды, представляет собой весьма интересный объект в этом плане. И, наконец, мы имеем тотально коррумпированную систему отношений в экономике, да и во всех других сферах тоже, и общественное сознание, в рамках которого криминал воспринимается как нормальный порядок вещей.

Не стоит обольщаться регулярно звучащими и у нас, и на Западе заявлениями о том, что кризис кончается. Это надолго. И со всем этим наследием нам придется плыть по внезапно заштормившему морю мировой экономики, где перед государствами действительно будут вставать очень серьезные проблемы выживания.

Bon voyage, господа! 